\title{
An Investigation of SCLEREMA NEONATORUM; with Special Reference to the Chemistry of the Subcutaneous Tissues. \\ (Part I.) \\ BY
}

G. A. HARRISON, B.A., M.D.,

Biochemist, The Hospital for Sick Children, Great Ormond Street, London;

WITH

\section{A HISTOLOGICAL REPORT}

BY

J. W. McNEE, M.D., F.R.C.P.,

Deputy Director of the Medical Unit, University College Hospital, London.

\section{Introduction.}

Sclerema neonatorum is a rare but interesting condition peculiar to infants. The extraordinary confusion that has existed in the past in regard to nomenclature will not be discussed. Instead the reader is referred to an article by Langmead(9). The five cases reported in this paper would probably be diagnosed as "pseudo-sclerema," using the term in the sense employed in Langmead's article. I personally would prefer to follow Paterson (27) in regarding them as examples of the milder type of true sclerema.

Dr. J. W. McNee first became interested in the disease in $1921^{(20)}$ when the first of the five cases was seen in consultation with Mr. C. C. Choyce and Dr. A. M. H. Gray. With Dr. Gray a preliminary communication was made at the Dermatological Section of the Royal Society of Medicine, but publication was postponed in the hope of obtaining further material for fuller chemical examination. In 1924 this opportunity arose. In the meanwhile I had learned of my colleagues' previous observations, and am greatly indebted to them for permission to include their findings in Cases I. and II. In this work I have also been aided by numerous other colleagues to all of whom I desire to express my thanks. I would mention particularly $\mathrm{Mr}$. H. J. Channon, of University College, who was responsible for many of the analyses in Cases III. and IV. and controls No. (a) and (d).* I wish to

* Mr. Channon has already published with the author an extract of the purely chemical findings in the Biochemical Journal, 1926. 
thank Mr. R. J. Bromfield and Mr. D. S. Martin for their invaluable assistance. The Medical Research Council very kindly made a grant towards the expenses of the original drawings.

First will be given the clinical findings in the five cases, with post-mortem reports in four. The fifth case recovered. Then in order the following investigations will be reported, viz., histological examination of the subcutaneous tissues, histochemical examination of crystals in subcutaneous fat, $\mathrm{X}$-ray examination of the subcutaneous tissue and related chemical findings, examination of the cyst fluid from Case III., and chemical investigation of subcutaneous tissues.

\section{Clinical Findings.}

A brief outline only of the clinical findings in the five cases will be given, since there is nothing to add to previous accounts. The reader will find a very full description with a bibliography exceeding 200 references to the literature up to 1895, in Ballantyne's work ${ }^{(2)}$. A more recent treatise to which reference should also be made is that of Paterson(27). Other papers of interest are those of Garrod(10 \& 11), Northrup(25), Sobel(33), Scott(30), and M'Neil(21). Other references will be found later in the different sections of this paper.

\section{Case I.}

L.W.H., male, aged six weeks, a first child, was admitted to University College Hospital, under Mr. C. C. Choyce, on January 23rd, 1921. The labour was normal, and nothing peculiar was observed in connection with the baby until the second day after birth, when a lump appeared on the left arm. This was thought to be an abscess, but was not at first opened. Lumps then appeared on other parts of the limbs and body. Subsequently an incision was made into the lump over the left deltoid muscle and a milky fluid escaped, but nothing resembling pus. The child was emaciated and pallid. He had never been breast fed. Irregular hard well-defined thickenings of the subcutaneous tissue were present over both upper arms, over the upper part of the back and the nape of the neck, and smaller areas of thickening over both thighs. The skin was firmly adherent to these swellings and was of a deep purplish colour, especially in the region of the left deltoid, where the swelling had undergone softening. The colour of the skin on the thighs was less purple. The milky fluid could be squeezed out in abundance from the incision into the lump over the deltoid muscle. This fluid, under the microscope, was found to contain myriads of acicular crystals, along with a certain number of cells of lymphocytic type. The fluid was examined under crossed Nicol's prisms, but the crystals were not observed to be doubly refracting to light. In considering subsequent observations this examination was probably wrong. Cultures of the fluid on all ordinary 
culture media remained sterile. Films examined for spirochætes by darkground illumination, and stained by Fontana's method, were all negative.

A Wassermann reaction on the mother's blood, carried out on January 24th, was completely negative. The child's blood is said to have been similarly examined previous to admission with negative result.

The child's weight on admission was $7 \mathrm{lbs} .8 \mathrm{ozs}$. On February 2nd, nine days after admission, it was 7 lbs. 10 ozs. Some days after admission the swelling in the deltoid region in relation to the incision became much enlarged, and definitely fluctuant. It was not reddened, however, and was not dealt with surgically. The temperature during the period of residence was much more often subnormal than normal, and was often lower at night time than during the morning. On several occasions, however, fever was present, although never for longer than 24 hours at a time, the temperature on three occasions being $99.2^{\circ}, 101^{\circ}$, and $100 \cdot 2^{\circ}$.

On February 3rd a wedge was removed from the swelling on the upper arm for diagnostic purposes.

The infant made no progress and died on February 9th, 16 days after admission.

Post-mortem report (Dr. J. W. McNee).

Child emaciated and pallid. Localised swellings in the subcutaneous tissues of the upper arms, back, and back of neck were still readily palpable in the cadaver. A fluctuant swelling over the left deltoid muscle was incised, and fully half an ordinary test-tube full of milky fluid esaped. This fluid was obviously not pus. On cutting into various parts of the subcutaneous tissues of the body the following points were made out. The subcutaneous fatty tissue was in most places reduced to a very thin layer. In other areas, corresponding to the palpable swellings, the subcutaneous fat was locally increased in amount, and macroscopically showed various differences from the normal. It was of a chalky white colour, without a trace of yellow, and the fibrous trabeculæ were very sharply defined so as to give the tissue an appearance almost approaching that of the pancreas or a salivary gland. It was firm to touch, and had a peculiar lard-like consistency.

The heart and lungs were normal. The stomach was much dilated and the pylorus was distinctly hypertrophied to form a mass about the size of a broad-bean. Liver, kidneys, spleen, and intestinal tract normal. The adrenal glands were small, and their cortex appeared to be devoid of lipoid fat. The testicles were undescended and lay in the inguinal canal.

Portions of skin and subcutaneous tissue were removed for histological and chemical investigation (see later). 
Case II. was under the care of Dr. R. Hutchison at the Hospital for Sick Children, Great Ormond Street.

P. A. D., female, aged 12 weeks, admitted September 22nd, 1921, with a three days' history of diarrhœa, but no vomiting. The baby was born at full term, the labour being normal. She was the second child, her brother being alive and well. The mother was healthy and had had no miscarriages. The baby was breast fed for a month and was then given Nestlé's milk and lime water. On examination there was marked dehydration, and a slight enlargement of the liver, but otherwise nothing abnormal. The temperature fluctuated between $98^{\circ}$ and $103^{\circ} \mathrm{F}$. Death occurred September 29th from ileo-colitis.

Two days before death the subcutaneous tissues became hard and boardlike. (Body temperature $103^{\circ} \mathrm{F}$.) On the next day the sclerematous deposits were more marked. There was no pitting on pressure.

Some authorities would probably place this case in a separate category from the other four on account of the clinical history. It has been included because the histological examination showed the same picture, though less marked, as in the other cases.

\section{Post-nortem report (Dr. Donald Paterson).}

The body was that of a fairly well nourished child, but the subcutaneous iissues were hard and firm due to the condition of sclerema. The weight was $8 \mathrm{lbs} .10 \mathrm{ozs}$. and the length 23 inches. Both small and large intestines had a flannel appearance throughout. Petechial hæmorrhages were present, and the colon was definitely thickened. No ulcers were seen. The mesenteric glands were much enlarged. The liver had a fatty appearance. The kidneys exhibited cloudy swelling and fatty degeneration, and uric acid infarcts were noted. Skin and subcutaneous tissue was removed from the buttocks and the abdominal wall for histological and chemical examination by Dr. McNee.

Dr. D. Nabarro isolated B. dysenteriæ (Flexner Y) from a scraping from the colon.

Case III. was under the care of Dr. Hugh Thursfield at the Hospital for Sick Children.

L. H., * female, aged 5 months, admitted April 3rd, 1924. The baby was born at full term, the labour being normal. Red patches " hard and raised" were noted on the skin of the arms on the first and second days of life. On the fifth day the arms and legs were "stiff." Later on, lumps appeared under the skin of the arms and legs. The weight at birth was $8 \frac{1}{2} \mathrm{lbs}$., and on admission $10 \frac{1}{4} \mathrm{lbs}$. The baby was bottle-fed from birth. It was given No. 1 Virol on the first day of life, and until admission it was fed

\footnotetext{
* This case was shown for Dr. Thursfield at the Royal Suciety of Medicine(37).
} 
on a mixture of Virol and cow's milk in the day time, and cow's milk and whisky (10 drops to a feed) at night. The patient was the youngest of a family of eleven, of whom nine were healthy and one died of marasmus.

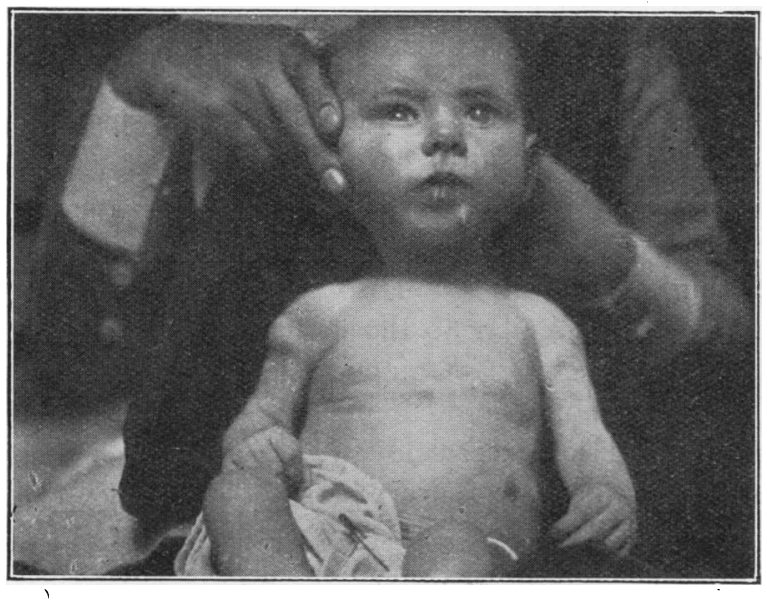

FIG I.

On examination the child appeared well nourished and normal in every way except for the subcutaneous tissues. Therein could be felt firm hard patches which were allherent to the skin and which did not pit on pressure. These were present in both arms, both forearms, both buttocks, the extensor surfaces of both thighs, both calves, and on the back. There was a small fluid cyst over each deltoid muscle (see Figure 1). One of these was aspirated and the contents examined chemically (see later). The Wassermann reaction was negative. The fæces were normal macroscopically and microscopically. Nothing abnormal was found in the urine.

On April 17th, 1924, a biopsy was performed by Mr. E. I. Lloyd, who removed a portion of the skin and subcutaneous fat from the right forearm. The wound healed by first intention. The histological and chemical examinations of the excised tissue are reported later.

Shortly after the operation the infant developed gastroenteritis from which it died on May 5th, 1924. The weight remained stationary from admission till the biopsy. Thereafter it fell rapidly from $10 \mathrm{lbs}$. $7 \mathrm{ozs}$. to $8 \mathrm{lbs} .6 \mathrm{ozs}$. During this period of decline, the subcutaneous lumps softened and became absorbed to a considerable extent. The temperature from admission until the operation was $97^{\circ} \mathrm{F} .-100^{\circ} \mathrm{F}$, though it exceeded $99^{\circ}$ on only a few occasions. After the operation until death it varied between $98^{\circ}$ and $102^{\circ}$.

Six days after the biopsy the blood was examined; the blood-sugar was $67 \mathrm{mgm}$. per $100 \mathrm{c.c}$. half an hour after a feed, and the serum cholesterol was 
only $59 \mathrm{mgm}$. per 100 c.c., whereas the blood of a control baby, 5 weeks old, contained $143 \mathrm{mgm}$. There was no lipæmia.

Post-mortem report (Dr. W. G. Wyllie).

The body was greatly emaciated: weight $7 \mathrm{lbs}$; length, $2 \mathrm{ft} .2 \mathrm{in.}$ A small cystic swelling, the size of a marble, was present under the skin of each arm, over the deltoid muscle. Under the skin of the forearms and of both legs were many small firm lumps. The skin over the buttocks was thick and brawny to the touch. Portions of subcutaneous fat were removed for chemical and histological examination (see later) from the buttocks and back of the thighs and arms. Throughout the fat thus removed were scattered minute cysts similar to those over the deltoids. Each cyst was full of a white, shiny, soft glistening material like " snow cream," which had a strong smell of lanoline and camphor. The subcutaneous fat elsewhere was dry and firm. The viscera in the thorax and abdomen (apart from the intestines), and the brain, revealed no abnormalities. Microscopical examination of sections of the pituitary; thymus, thyroid, pancreas and suprarenals, revealed nothing of note.

Case IV. was under the care of Dr. H. C. Cameron at Guy's Hospital.

S. E. B., male, aged 4 days, admitted April 3rd, 1924. The baby was born with blue asphyxia, the labour being normal. When 24 hours old cyanosis recurred, but there was no distress. Subsequently there were several similar but slighter attacks of cyanosis. There was diarrhœa with green stools, but no vomiting.

The sclerematous deposits were similar to those described in Case III. but were more extensive : both cheeks were involved. The baby took well from the bottle. The temperature fluctuated slightly on either side of $98^{\circ} \mathrm{F}$, but was never definitely subnormal. On two or three occasions it rose to $101^{\circ}$ and $103^{\circ}$. The weight on admission was 2,800 grammes, and had risen slowly to 3,000 grammes when discharged from hospital on May 7th, 1924. The following estimations were made on the blood: cholesterol in whole blood $183 \mathrm{mgm}$., in plasma $120 \mathrm{mgm}$. per 100 c.c. (Prof. A. Stokes) : sugar in whole blood $61 \mathrm{mgm}$., inorganic phosphates in serum $5 \mathrm{mgm}$., serum calcium $9 \cdot 3 \mathrm{mgm}$. per 100 c.c. (Dr. W. W. Payne). The plasma and serum were both definitely lipæmic. A blood count resulted as follows : hæmoglobin 74 per cent. : erythrocytes $3,960,000$ : leucocytes 10,200 of which the polymorphs constituted $64 \cdot 25$, lymphocytes $32 \cdot 25$, large mononuclear cells $1 \cdot 75$, eosinophils $1 \cdot 5$, and transitional cells $0 \cdot 25$ per cent.

The infant was readmitted on July 2 nd with infective enteritis, from which it died the next day.

The post-mortem examination (Prof. A. Stokes) revealed nothing of note apart from the condition of the intestines and the subcutaneous fat; some of the latter was excised for histological and chemical examination (see later). 
Case $V$. was under the care of Dr. Hugh Thursfield at the Hospital for Sick Children.

E. H., female, aged 6 weeks, admitted November 11 th, 1924 . The baby was brought to hospital on account of "fits" and "blue turns " which started in the first week of life. She was born at full term, the labour being normal. She is the third child, the other two being alive and well. The mother is healthy and has had no miscarriages. Weight at birth $7 \mathrm{lbs}$. and on admission $7 \mathrm{lbs}$. and rose gradually to $7 \mathrm{lbs} .8 \mathrm{ozs}$. on December 12th. Temperature fluctuated between $97^{\circ}$ and $99^{\circ} \mathrm{F}$. The liver and spleen were both enlarged slightly, otherwise the various systems appeared normal. The condition of the subcutaneous tissues was similar to that in the other cases, but much less marked in degree. There was no cyst formation and no deposits in the cheeks. The mother noticed that the buttocks were hard in the first week of life. The Wassermann reaction was negative. Nothing abnormal was found in the urine. On November 11 th the blood was examined: serum calcium, 15 mgm., plasma inorganic phosphate $4.8 \mathrm{mgm}$., and plasma cholesterol 140 mgm. per 100 c.c.

The infant slowly gained weight and improved generally, the sclerematous deposits slowly absorbing till recovery became complete in the sixth month (see later in section on X-ray examination). On February 5th, 1925 , a second examination of the blood was made: serum calcium 11.8 mgm., serum cholesterol $178 \mathrm{mgm}$. per 100 c.c.

At the age of 10 months the infant still had fits though these were less severe and less frequent. It was very doubtful whether the child had ever been able to see. Both the mother and the ward-sister considered she was blind. Nothing abnormal was found on examining the fundi and optic discs. An X-ray of the skull showed no abnormality.

\title{
Histological Examination of the Subcutaneous Tissues.
}

\author{
(J. W. MçNeE.)
}

Case 1.

(Biopsy and Autopsy Material.)

A few days before death, a small wedge-shaped piece of skin and subcutaneous tissue had been removed, for histological examination, from a large firm swelling over the right deltoid muscle. At the necropsy a number of pieces of skin and subcutaneous tissue were taken from different situations, so as to include specimens looking very different to the naked eye. The tissue comprised some of the obvious swellings, other areas where the skin was only slightly raised above the neighbouring parts, and also segments of what appeared to be the normal skin and subcutaneous tissues of the infant. 
Some of the tissue was fixed at once in 10 per cent. formalin, while the remainder was put aside for chemical analysis. Sections of the material fixed in formalin were cut both by the freezing microtome and after paraffin embedding. The frozen sections were stained in various ways, chiefly with Hæmalum and Sudan III, and with Lorrain Smith's Nile Blue Sulphate. The paraffin sections were stained in the usual way with Hæmalum and Eosin.

The histological changes are clescribed below, and are most striking in the subcutaneous tissue from the obvious swellings. The lesion is the same, but less fully developed, in places where the skin is only slightly raised above the general body surface. In the parts noted macroscopically as normal, the pathological changes are still found microscopically, but are minimal in amount. It may be said at once that the true skin is normal histologically, the lesion being strictly confined to the subcutaneous tissues.

In sections of tissue from one of the obvious swellings, the first thing noted, both in frozen and paraffin sections, is the very great increase in thickness of the fibrous trabeculæ which separate the lobules of fat. This was also noticed macroscopically.

A separate description is necessary for the frozen and paraffin sections, since the two methods specially favour the examination of different histological details.

In a paraffin section, from which all fat has of course been removed, the structure of the fibrous trabeculæ is seen to be much altered from the normal. The fibrous tissue is increased in amount, and in many situations is broadened out into irregular patches, some containing fat spaces in small numbers embedded in them, others entirely devoid of fat cells. Throughout the tissue, and more especially in relation to the empty circles representing fat cells, are numerous irregularly distributed thin clefts, indicative of the presence of crystals dissolved out in the paraffin process. With higher magnification these clefts are seen completely to surround every fat cell, and in a few places where a fat cell has been cut in tangential section near its surface the clefts are found crossing the cell in all directions. It is evident that they entirely surround the cells like the cover of a ball. Similar clefts are also numerous in the fibrous tissue quite away from any recognisable fat cells. Lying in contact with many of the clefts are elongated giant cells, with large multiple nuclei. Another histological change is noted in parts of the tissue where fat cells have lain close together, separated by only a small amount of connective tissue. This is the deposition of lime salts, recognised by their density, shape, and deep purple staining reaction with hæmalum. These salts of lime are seen to form a coating to the fat cells, and where they occur the clefts are absent. Throughout the fibrous tissue generally, considerable infiltration with round cells is seen.

In frozen sections, the finer structure of the fibrous tissue is less obvious, but the fat cells and the undissolved crystals can be more carefully ex?mined. 
The appearances are well shown in the coloured plate (Fig. 2). The crystals are seen in enormous numbers, acicular in shape, and lying in bunches like sheaves of corn. They are greyish in colour under the microscope, and are quite unstained either by Sudan III or by Nile Blue Sulphate. The fact that the fat cells (containing neutral fat) are surrounded by these crystals, inferred from the paraffin sections, is entirely confirmed. The fat cells themselves take up the Sudan III and Nile Blue stains quite well, but show various differences from the normal colour by these methods. The colour is not so bright as usual, but flecked and mottled with grey. It is impossible to make out definitely, even in the thinnest frozen sections, whether this alteration in colour is due to crystals shining through from behind, or to an actual abnormality in the fat content of the cells. On examining the frozen sections through crossed Nicol's prisms, all the crystals are found to be doubly refracting to light. The fat cells themselves show numerous points of double refraction to light, but the appearance is not uniform. It is impossible to be sure if the appearance is due to material contained within the cellular protoplasm, or to fragments of crystals lying behind or on top of the cells.

Ciase II.

(Autopsy Material.)

Histologically, a very mild degree of the changes seen in Case I. is recognised. In paraffin sections there is an increased thickness of the fibrous trabeculæ, which are here and there widened out into nodes of cellular tissue, surrounding some fat cells, and containing only an occasional giant cell. In one portion only, close below the cutis, clefts are seen from which crystals have obviously been dissolved out. The giant cells are most numerous in the area surrounding these clefts. The blood vessels in the sections examined do not show endarteritis, as in other more advanced cases in the series. No calcification of fatty cell envelopes is made out.

Case III.

\section{(Biopsy and Autopsy Material.)}

Here the appearances in paraflin sections (Figs. 3 and 4) are closely similar to those in Case I., but giant cells are an even more striking feature while calcification is absent. It happened that sections were cut so as to include an area where the tissue had entirely broken down to leave a space filled with milky fluid (Figs. 3 and 6). The walls of this space are formed by rows of giant cells, which give a very striking histological picture. Endarteritis of small arterioles (Fig. 5) in the subcutaneous tissue is well marked, further evidence of the chronic inflammatory changes which have taken. place.

In frozen sections stained by Sudan III and examined under crossed prisms, the changes noted are identical with those of Case I., doubly 
refracting acicular crystals being visible almost everywhere. An interesting finding is made out by examination of the wall of the cavity (Fig. 6) which contained milky fluid. Various tags of fatty tissue, containing both neutral fat and crystals, are attached to the wall and project into the cavity. It is obvious that the cavity has been formed simply by death of a small lobule of fatty tissue, and liberation of the neutral fat and crystals from the cells.

Case IV.

\title{
- (Autopsy Material.)
}

This is the most striking case histologically of the whole series, owing to the depth of subcutaneous tissue involved. The changes are the same as described for Case I. The formation of firm fibrous trabeculæ, the occurrence of abundant giant cells, of necrosis of fat cells, of calcification, and of inflammatory changes in small arterioles (endarteritis obliterans) are all visible abundantly. In this case too the firm fibrous trabeculæ in the area involved continue as thick strands into the muscular tissue below, but giant cell formation does not extend deeper than the subcutaneous fatty tissue.

In frozen sections, stained for fat, the sheaves of crystals between and surrounding the fat cells are seen in enormous numbers, and through crossed Nicol prisms the picture is brilliant (Fig. 7).

It will be seen from Dr. McNee's report that all four cases showed the same histological picture but in varying degree. The fifth case recovered and no biopsy was made: The histology of sclerema neonatorum has been described previously, for example by Ballantyne(2), Paterson( ${ }^{(27)}$, Keilmann(13), and Brinchmann(5). Keilmann describes his case as "scleroderma." His two illustrations are exactly similar to our paraffin sections.

\section{Histochemical Examination of Crystals in Subcutaneous Fat.}

\author{
(G. A. HARrison.)
}

In this section of the paper are recorded attempts to determine the nature of the crystals in the subcutaneous fat.

\section{Observations on Sclerema Crystals.}

The appearance of the crystals in stained frozen sections as seen under the polarising microscope is illustrated in Fig. 7. They are readily seen under the polarising microscope in unstained sections also, and this fact 
SCLEREMA NEONATORUM

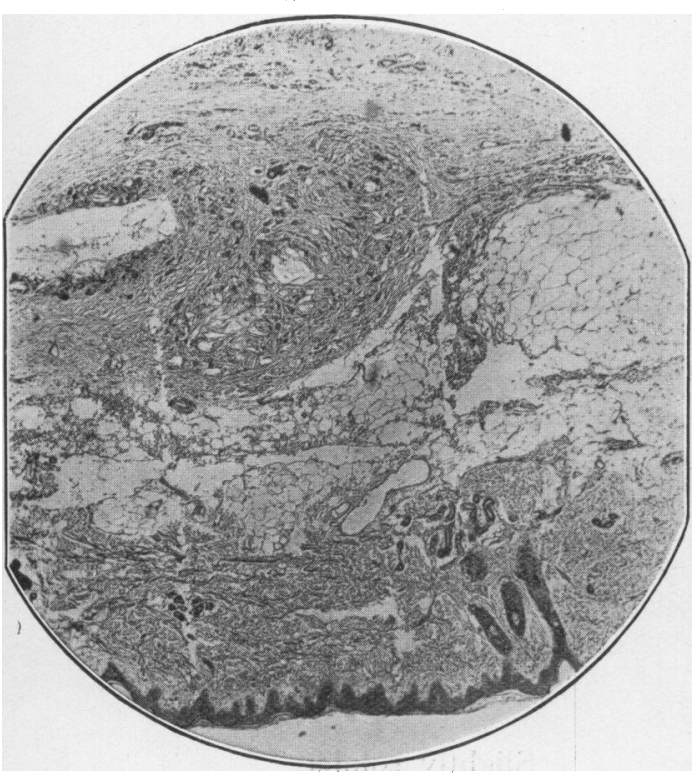

Fig. 3.

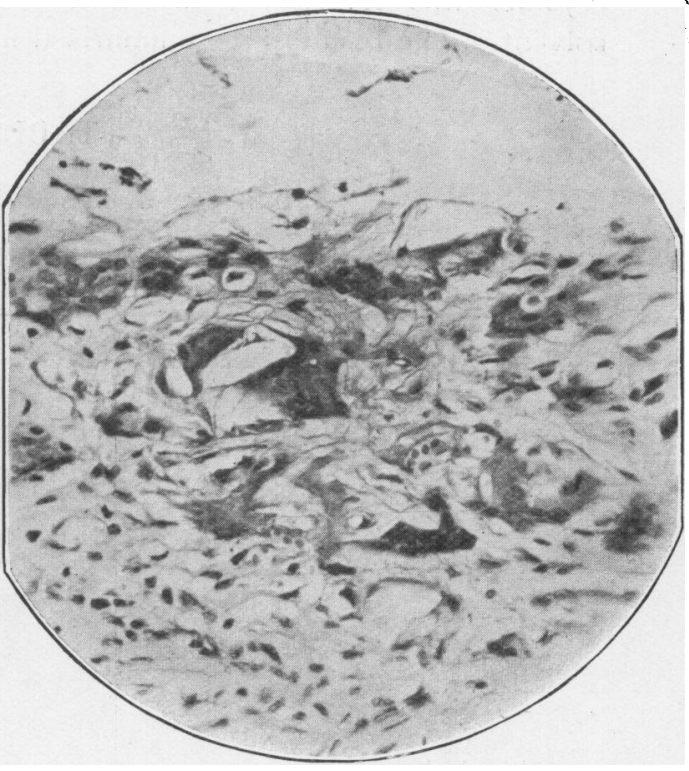

Fig. 4 ,

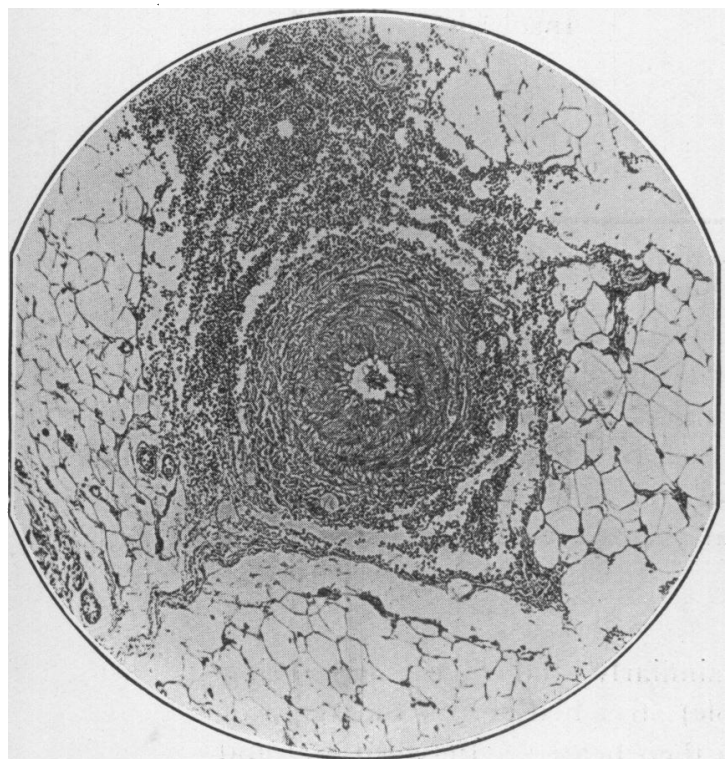

Fig. 5.

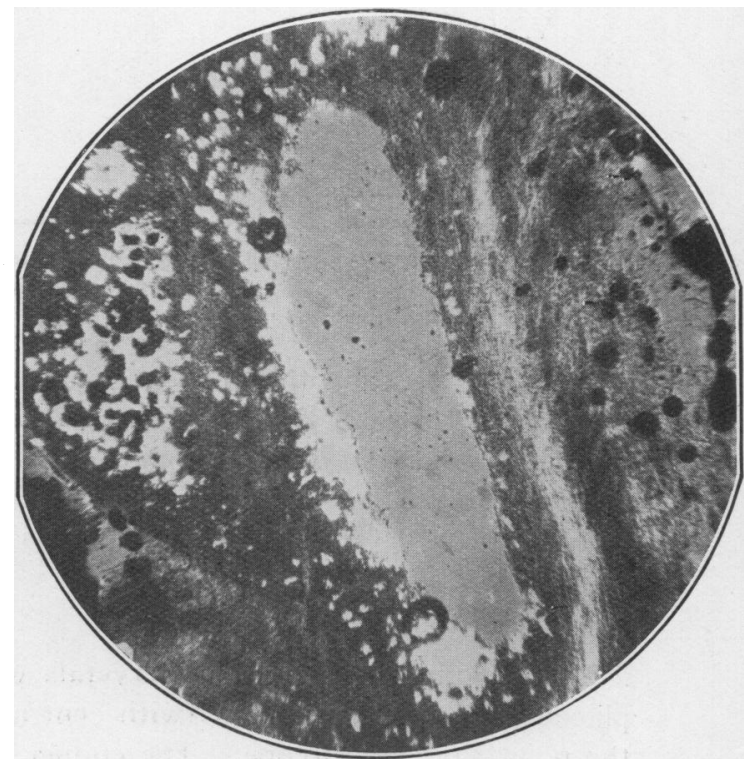

Fig. 6. 
made it easy to watch the action of solvents on the crystals. A bunch of crystals was carefully focussed and the section was then flooded with the solvent. The results are summarised in Table I. :-

\section{TABLE I.}

Action of solvents on sclerema crystals.

(Frozen sections : polarising microscope.)

\begin{tabular}{|c|c|c|c|}
\hline Solvent. & Cold. & WARM. & \\
\hline Ether. & "Insoluble" & Soluble. & \\
\hline Petroleum ether. & , & ", & \\
\hline Acetone. & , & $"$ & \\
\hline Pyridine. & " & " & \\
\hline Alcohol. & ", & Slightly soluble & $*$ \\
\hline Acid Alcohol (1\% HC1). & " & ", & $*$ \\
\hline Alcoholic soda $\frac{N}{1 \pi}$. & , &, & * \\
\hline Water. & ", & Insoluble. & * \\
\hline $\mathrm{HC} 1 . \mathrm{aq} \frac{\mathrm{N}}{\overline{1}(i \cdot}$ & , & , & $\because$ \\
\hline $\mathrm{NaOH}$. aq $\underset{i \sigma}{i}$ & ", & , & $\because$ \\
\hline
\end{tabular}

* Between $40^{\circ}$ and $50^{\circ} \mathrm{C}$. the crystals melt, to reappear in situ on cooling and in the original form.

It is interesting to note that the crystals do not dissolve when treated in this way at "room temperature." It is realised, of course, that the actual temperature of the solvent would in some cases be considerably below room temperature owing to rapid evaporation of the solvent when spread in a thin film on a slide. Table I. shows that the sclerema crystals have the typical solubilities of a neutral fat.

The action of heat on the crystals was similarly studied, the slide being placed on a piece of copper (with central hole) stretched across the stage of the polarising microscope. The copper was then heated. Between $40^{\circ}$ and $50^{\circ} \mathrm{C}$. the crystals melted and disappeared suddenly. On cooling the crystals suddenly flashed into sight again like so many stars coming out, and 
in their original form. There was no suggestion of the formation of liquid crystals. A microscope warm stage for careful measurement of temperature was not available, but the following observations gave a rough measure of the melting point of the crystals in the sections. When placed in an incubator at 370 to $40^{\circ} \mathrm{C}$. for half an hour or more, the crystals did not melt, but in a hot-air oven at $50^{\circ} \mathrm{C}$. they did. The melting point therefore lay between $40^{\circ}$ and $50^{\circ} \mathrm{C}$.

Having observed crystals in the frozen sections, the separated fat was next examined. A piece of sclerematous subcutaneous fat was warmed on a microscope slide. The melted out fat was covered with a coverslip and allowed to cool to room temperature. As would be expected this separated fat contained anisotropic crystals similar in every respect to those seen in the frozen sections. If the separated fat was cooled quickly the crystals appeared as isolated rods or short needles. If it was cooled slowly, and particularly if it was kept for a few days, the crystals tended to form in tufts of acicular crystals. In their solubilities and melting point, etc., these crystals in the separated fat behaved in every way similarly to the crystals in the frozen sections.

Having observed that the sclerema crystals were soluble in ether, the ether extract of sclerematous subcutaneous fat was next examined. A drop of this was mounted under a coverslip, cooled and examined as before. It was found to contain abundant anisotropic crystals, exactly similar in appearance and properties to those found in the frozen sections.

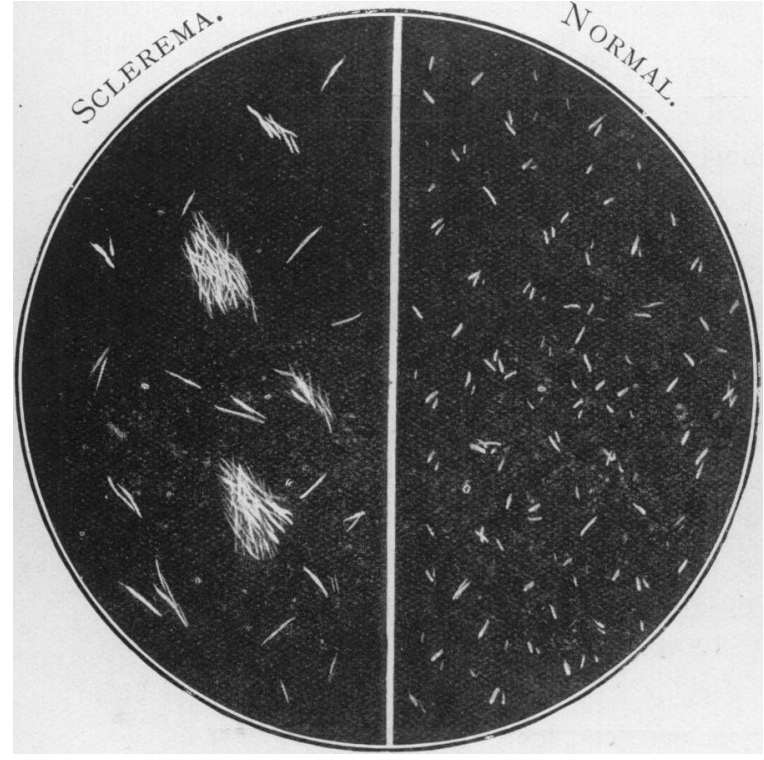

Fig. 9.

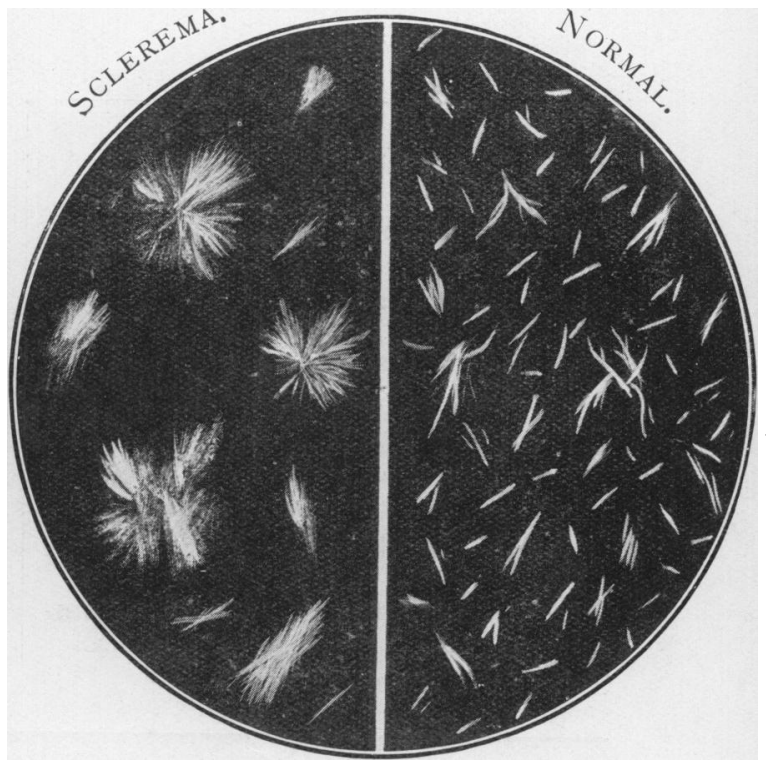

Fig. 10. 
Similar crystals were found also in the fluid aspirated from a cyst in the subcutaneous fat of Case III. (see later).

$$
\text { Observations on "Normal" Crystals. }
$$

The next step obviously required was to make control observations. It ivas found that the subcutaneous fat of children dying from other diseases, and the subcutaneous fat removed at operation from children requiring surgical treatment, also contained doubly refracting crystals which were very similar in appearance to those seen in sclerema fat.

The appearance of these crystals as seen in stained frozen sections is illustrated in Fig. 8. Similar crystals were found in the separated fat and in the ether extracts of non-sclerematous children. Fig. 9 illustrates the crystals in frozen sections of sclerematous and non-sclerematous fat (" normal" fat) respectively. Fig. 10 gives a corresponding comparison between the crystals in the ether extracts from the two sources.

The experiments on the solubilities and the effect of warming were repeated on the "normal" crystals, and the results compared with those in sclerema (Tables II. and III.).

TABLE II.

Crystals in Frozen Sections.

\begin{tabular}{|c|c|}
\hline SCLEREMA. & Normal. \\
\hline Acicular, in tufts. & Short rods, "bacilli." \\
\hline Longer than normal. & Shorter than sclerema. \\
\hline In fat globules and free. & In fat globules only. \\
\hline Melt at $40^{\circ}-50^{\circ} \mathrm{C}$. & Melt about $30^{\circ} \mathrm{C}$. \\
\hline $\begin{array}{l}\text { On cooling reappear quickly above } \\
\text { room temperature. } \\
\text { Reappear in original form and no } \\
\text { liquid crystals. }\end{array}$ & $\begin{array}{l}\text { On cooling reappear more slowly, c.g., } \\
\text { in a few mini:tes at room tempera- } \\
\text { ture. }\end{array}$ \\
\hline $\begin{array}{l}\text { "Insol." in pet. ether at room tem- } \\
\text { perature. } \\
\text { Sol. in warm pet. ether. }\end{array}$ & $\begin{array}{l}\text { Dissolve rapidly in pet. ether at room } \\
\text { temperature. }\end{array}$ \\
\hline $\begin{array}{l}\text { In the frozen sections the " } \mathrm{n} \\
\text { temperature than the sclerema crys }\end{array}$ & $\begin{array}{l}\text { ormal " crystals melted at a lower } \\
\text { als. This does not necessarily imply }\end{array}$ \\
\hline
\end{tabular}




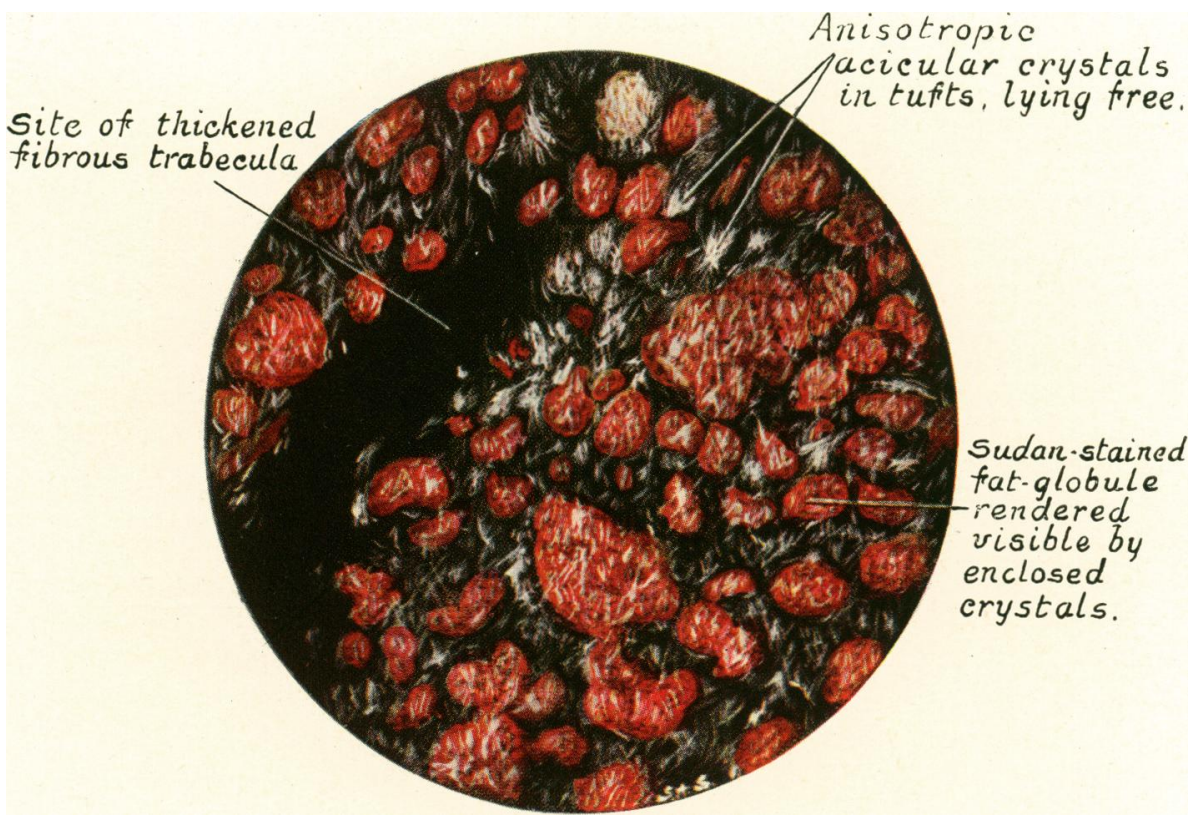

Fig. 7

Frozen section of subcutaneous fat from case of sclerema.

Sudan III. Nicol's crossed. $\frac{2}{3} r d s$ obj. No. 4 eyepiece.

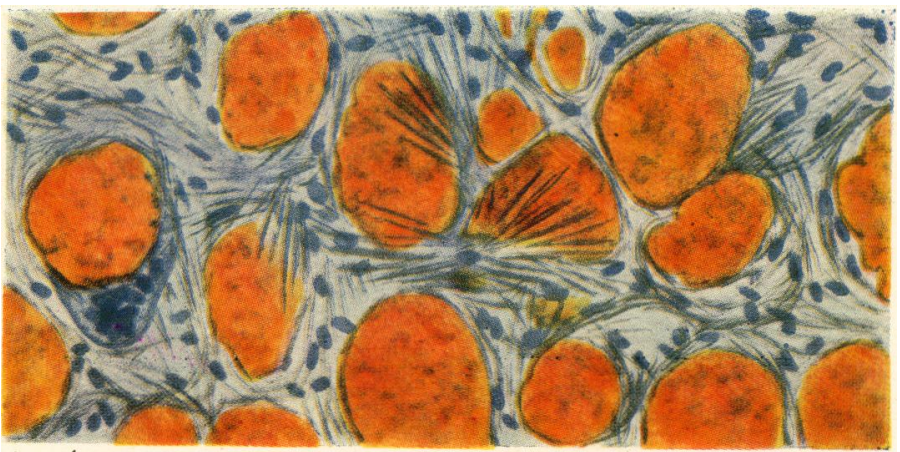

A. K : 1 AXWELL.

Fig. 2 


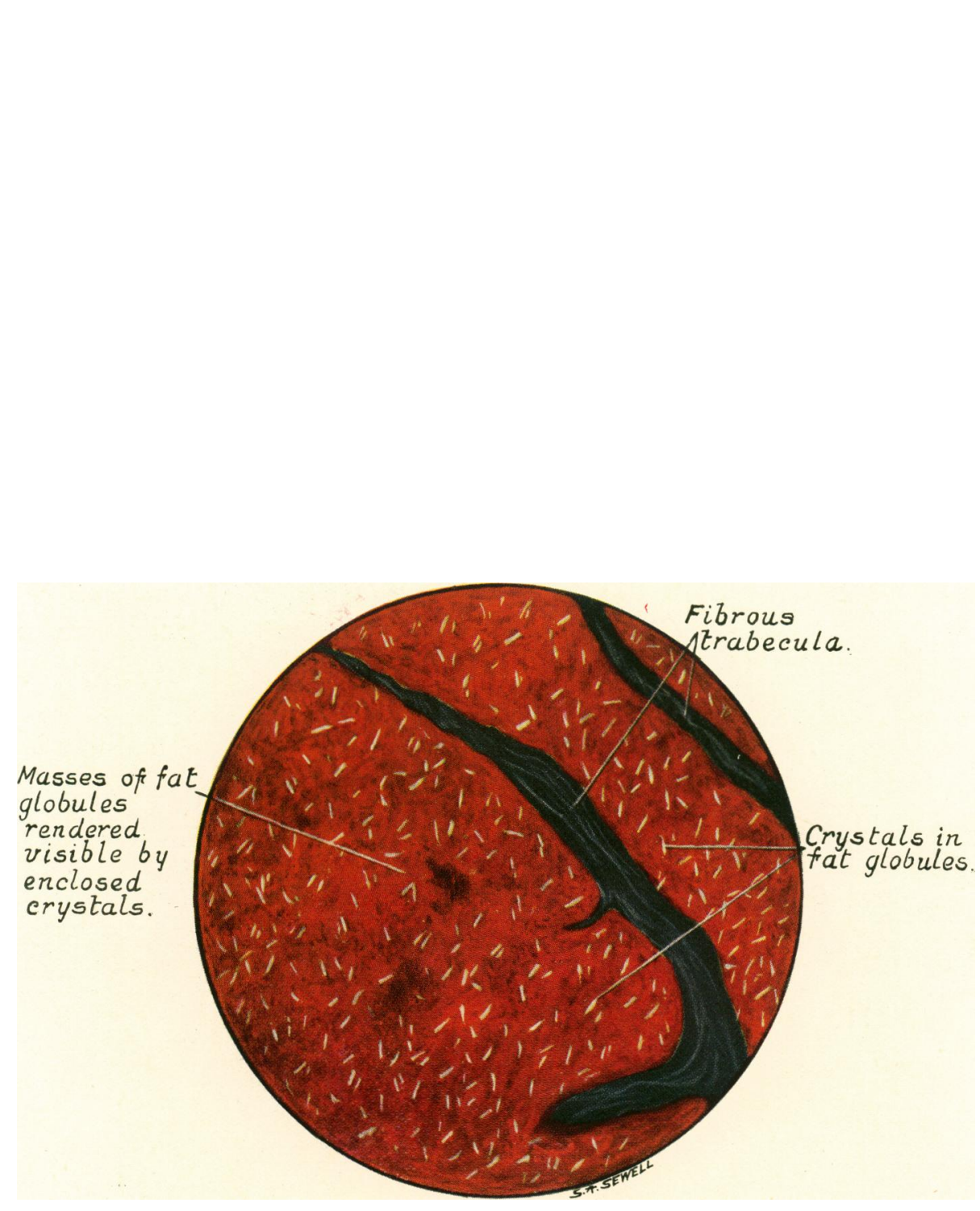

liig. 8

Frozen section of normal subcutaneous fat

Sudan III. Nicol's crossed. $\frac{2}{3}$ rds. obj. No. 1 eyepiece. 
that the crystals are different. It might easily result from the media in which the crystals were suspended being of different compositions in the two cases. That this is a possible explanation is seen from Table III.

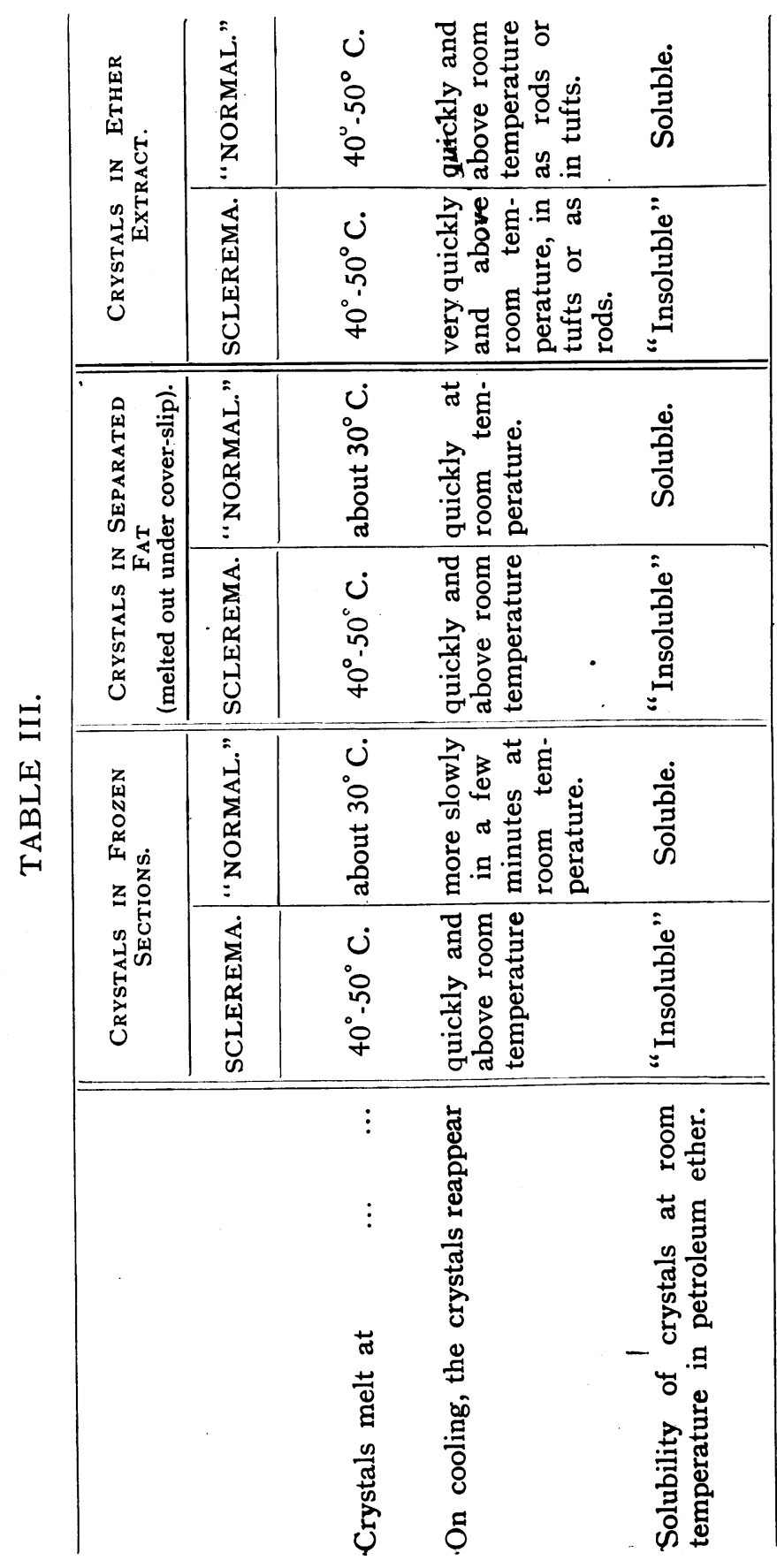


It will be noted that when the "normal crystals" are separated by ether extraction* their melting point rises.

Apart from the slight difference in solubility in petroleum ether (Table III.), the normal crystals behaved towards solvents in exactly the same way as sclerema crystals.

Presumably the " normal" crystals must be either stearin or palmitin, or both. In view of the great similarity between the normal anci the sclerema crystals, some observations were made on crystals of pure tripalmitin, and on crystals of pure palmitic acid.

\section{Observations on crystals of pure palmitin. $\dagger$}

Some pure powdered palmitin (M.P. 620-63.5० C.) was recrystallised slowly from ether at $0^{\circ} \mathrm{C}$. Beautiful tufts of acicular crystals were obtained. These crystals were anisotropic. This point is emphasised, because most books on histology do not consider the possibility of crystals in frozen sections being palmitin (or stearin). In fact they lead the reader to believe that anisotropic crystals must be lipoids. Palmitin and stearin in the liquid state are not doubly refracting, but when crystalline they are. This fact is well known to organic chemists, who in practice frequently employ the polarising microscope merely to see whether a particular organic compound with which they are dealing is crystalline. In other words the property of double refraction is the rule amongst organic compounds when in the crystalline state.

Some of the palmitin crystals were spread on a slide under the polarising microscope. The slide was flooded with ether. At this temperature-the temperature of rapidly evaporating ether-the crystals were not appreciably soluble.

On treating the palmitin crystals with petroleum ether in the same way they did dissolve. In this respect they resembled in behaviour the crystals in the ether extracts from non-sclerematous tissue. In their behaviour to other solvents they resembled exactly the sclerema crystals (see Table I.)

Some of the palmitin crystals were heated on the stage of the polarising microscope in the way previously described until they melted to form oily droplets. These droplets were of course isotropic. On cooling, crystals suddenly appeared in each globule as so many stars coming out, providing an exactly similar picture to that seen in the frozen sections and ether extracts of subcutaneous fat.

* The ether extract of the subcutaneous fat of adults contains similar crystals. Mitchell(22), working on the perirenal fat of an adult, crystallised similar crystals from ther. Under the microscope his crystals somewhat resembled those frequently obtained from flare lards. I have often seen such crystals in the cooled concentrated ethereal solutions of fat obtained by extraction in a Soxhlet apparatus. Frozen sections of the subcutaneous fat of adults do not as a rule show neutral fat crystals. Occasionally, however, in sections which have been kept for a long time there is a separation of these crystals.

t I am greatly indebted to Professor J. ('. I)rummond for the specimens of pure palmitin, and palmitic acid, 
Similar experiments with pure palmitic acid.

Experiments similar to those with palmitin were repeated on pure palmitic acid.

Palmitic acid, when crystalline, is anisotropic. Palmitic acid is very much more soluble in ether and in petroleum ether under the above conditions, than either palmitin or the crystals observed in our sections and in the ether extracts from sclerematous and non-sclerematous subcutaneous fat. Moreover of course palmitic acid behaves. differently with alcoholic soda. On warming very slightly, palmitic acid crystals mounted in alcoholic soda $\left(\frac{N}{10}\right)$, are seen to go into solution. On running a few drops of water under the cover-slip an obviously soapy solution results, and crystals are no longer visible under the polarising microscope.

When palmitin or the ether extract from subcutaneous fat (sclerematous or " normal") is similarly treated, the crystals do not go into solution in alcoholic soda (or only to a very slight degree, see Table I.). . The crystals melt if the temperature is raised sufficiently high. On running a few drops of cold water under the cover-slip, a suspension of fat is obtained but no suggestion of a soapy solution. Moreover, the crystals of the neutral fat are again visible under the polarising microscope, suspended in the water.

\section{Other Tests on Sclerema Crystals.}

Microchemical tests for cholesterol in both normal and sclerema frozen sections were negative. The crystals themselves (normal and sclerema) were stained neither by Sudan III nor by Scharlach $\mathrm{R}$ nor by Nile Blue Sulphate.

Langer(15) in 1881 referred to the presence of crystals in the subcutaneous fat and discussed the likelihood of their being stearin and palmitin. He noted that the so-called " margarin" crystals seen in the fat of adults had melted by the time the temperature had been raised to $37^{\circ} \mathrm{C}$., and considered that they first appeared after death. He stated, however, that a large part of the fat in the fat-cells of infants was solid and opaque at temperatures above body-heat. He declared that this fat did not became fully soft till $40^{\circ} \mathrm{C}$.

No doubt most histologists have noted that fat crystals may frequently be seen in frozen sections of subcutaneous fat, but very few references to the fact are made in the literature. In truth it is noteworthy that in discussions on crystals observed in pathological subcutaneous tissue, it is only rarely that the possibility of their being neutral fats is raised. Indeed, a study of the literature of the last 40 years reveals a large number of instances in which acicular crystals have been assumed to be fatty acids without there keing any che nical evidence whatever as to their nature. Again, anisotropic 
acicular crystals have almost invariably been assumed to be cholesteryl esters or " cholesterol fatty-acid mixtures"; the possibility of their being neutral fat crystals has scarcely been mooted.

\section{X-Ray Examination* of Subcutaneous Tissue and Related Chemical Findings.}

Case III. was X-rayed at the suggestion of Dr. Hugh Thursfield, with the result depicted in Fig. 11. In Case V. the findings were similar. (Fig. 12.) Case IV. was $X$-rayed at Guy's Hospital with negative result. This may have been due to the use of rays which were too hard, since chemical analysis showed a marked increase of calcium in the subcutaneous tissues. (Table IV.) In a series of non-sclerematous children X-rayed in the same way as the sclerema cases, similar opacities in the subcutaneous fat have never been observed.

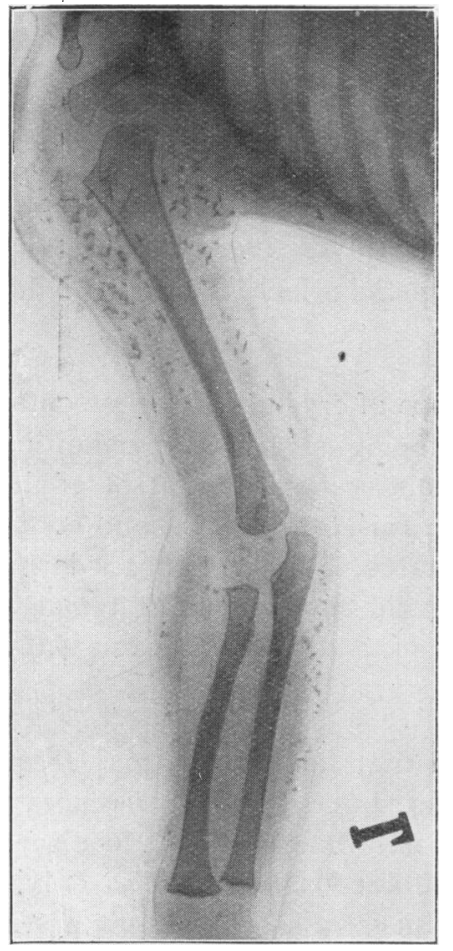

Fig. 11 (a).

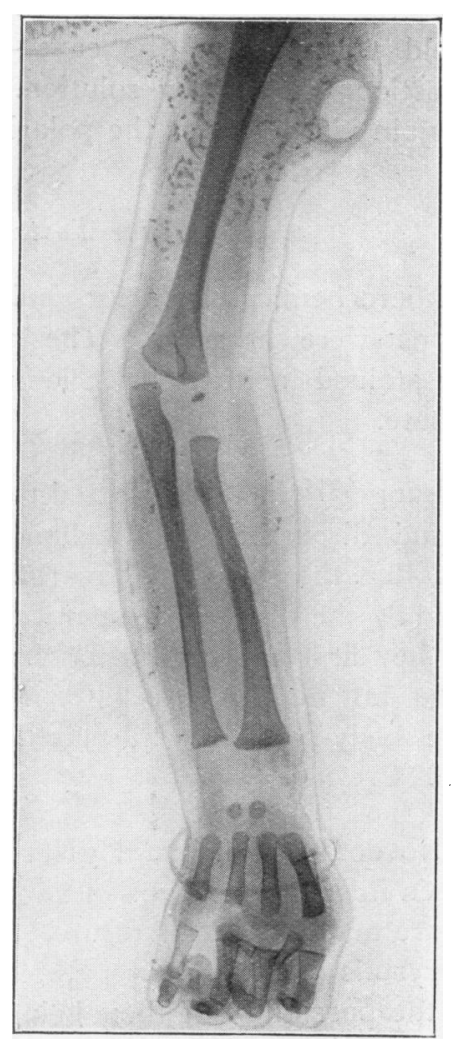

Fig. 11 (b.)

\footnotetext{
* I am indebted to Dr. B. Shires for the X-ray examination in Cases III. and V,
} 


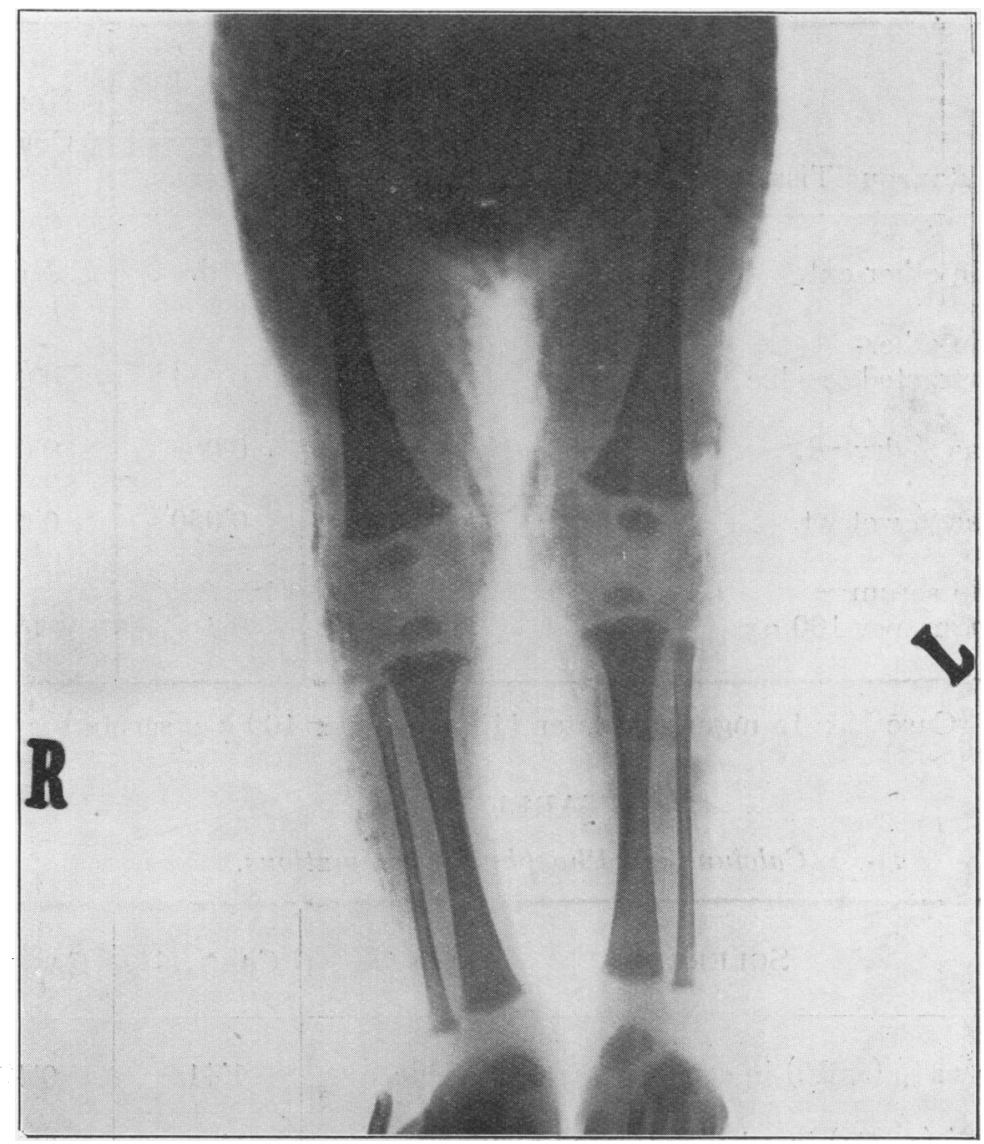

Fig. 12.

The results of estimations of calcium and of total phosphorus in the "ether-extracted residue" from Cases III. and IV. are shown in Tables IV. and V. Case V. recovered and no biopsy was performed. No calcium and phosphorus estimations were made in Cases I. and II. These results confirm the presence of the calcification suggested by the .histological examination. They provide a likely explanation of the X-ray appearances.

There was no direct evidence as to the form in which calcium existed in the subcutaneous fat, but it was of interest to calculate the ratio of calcium to phosphorus (Table V.). These figures are not contrary to the natural assumption that the calcium was combined as phosphates. 
TABLE IV.

Calcium Determinations.

\begin{tabular}{|c|c|c|c|c|}
\hline Subcutaneous Tissue. & Biopsy. & $\begin{array}{l}\text { III. } \\
\text { Autopsy. }\end{array}$ & $\begin{array}{l}\text { CASE IV. } \\
\text { Autopsy. }\end{array}$ & $\begin{array}{l}\text { Normal } \\
\text { Control. }\end{array}$ \\
\hline $\mathrm{Ca}$ in ether ext. & Nil. & Nil. & Nil. & Nil. \\
\hline $\begin{array}{l}\mathrm{Ca} \text { in ether- } \\
\text { extracted residue }\end{array}$ & 0.262 & 2615 & 0.254 & 0.072 \\
\hline $\mathrm{Ca}$ as $\%$ dry wt. & 0.072 & $1^{\circ} 284$ & $0^{\circ} 065$ & $0^{\circ} 010$ \\
\hline $\mathrm{Ca}$ as $\%$ wet wt. & $0^{\circ} 033$ & 0.505 & $0^{\circ} 030$ & $0^{\circ} 007$ \\
\hline $\begin{array}{l}\mathrm{Ca} \text { in serum- } \\
\text { mgm. per } 100 \text { c.c. }\end{array}$ & - & - & $9 \cdot 3$ & 9 to 11 \\
\hline
\end{tabular}

(Case V.: $15 \mathrm{mgm}$. and later $11^{\circ} 8 \mathrm{mgm}$. per 100 c.c. serum.)

TABLE V.

Calcium and Phosphorus Estimations.

\begin{tabular}{|c|c|c|}
\hline SClerema. & CASE III. & Case IV. \\
\hline Phosphorus \% (as P.) in ether-extracted residue. & $1 \% 41$ & 0.47 \\
\hline Calcium \% (as $\mathrm{Ca}$ ) in ether-extracted residue. & $2 * 62$ & $0 \cdot 25$ \\
\hline The ratio $\mathrm{Ca} / \mathrm{P}$ in ditto. & $1 \cdot 85 / 1$ & $0^{\circ} 54 / 1$ \\
\hline The ratio $\left(\mathrm{Ca} / \mathrm{P}\right.$ in $\mathrm{Ca}_{3}\left(\mathrm{PO}_{4}\right)_{2}$ is & $1^{\bullet} 965 / 1$ & \\
\hline P. calc ${ }^{\text {d }}$ to combine with $\mathrm{Ca}$ if as $\mathrm{Ca}_{3}\left(\mathrm{PO}_{4}\right)_{2}$ & $1 \cdot 33$ & $0 \cdot 13$ \\
\hline Therefore P. existing in other forms & $0^{\circ} 08$ & 0.34 \\
\hline
\end{tabular}

It is of interest to note that in Case $\mathrm{V}$. the $\mathrm{X}$-ray appearance persisted long after the hard masses had disappeared. On November 4th, 1924, the $\mathrm{X}$-ray appearances were typical (cf. Fig. 12). On January 2nd, 1925, it was difficult (by palpation) to detect anything abnormal with the exception of a slight thickening in the subcutaneous fat round the anus, but the $\dot{X}$-ray appearances were but little altered. In February, 1925, the calcified patches 
were still visible in the radiograms, but appeared less marked. Clinically at this time the subcutaneous fat everywhere was of a normal consistency. In July, 1925, no opacities were visible in the X-ray plates.

Morse ${ }^{(24)}$ has reported a case of calcification of the skin in a child aged $3 \frac{1}{2}$ years. He presents radiograms which are very similar in appearance to ours though more marked in degree. A lump supposed to be an absorbing subcutaneous abscess was first noticed when the child was 2 . This may very well have been a case of sclerema, although the child was older than other recorded cases.

\section{EXAMINATION OF THE CYST FLUID FROM CASE III}

(a) Fluid aspirated during life.

The cyst over the right deltoid was aspirated without drawing any blood. About 1 c.c. of an oily pale straw-coloured liquid was obtained. Whilst drawing it into the syringe it was noted that there were minute white lumps in suspension in the oily fluid. These lumps quickly increased in size on cooling. They did not go back into solution until the fluid was heated to nearly $50^{\circ} \mathrm{C}$. On examination of stained films under the microscope no cells and no organisms were seen. Cultures were not made. Under the polarising microscope the white lumps were seen to be masses of acicular anisotropic crystals, in every way similar in appearance to those seen in the frozen sections and ether extracts. The calcium content was $41 \mathrm{mgm}$. per 100 c.c. fluid, and the total cholesterol (colorimetric determination) was 1.5 per cent. (approx.).

(b) Fluid obtained post-mortem.

Post-mortem a number of small "cysts" were found scattered throughout the indurated subcutaneous fat of the arms, forearms, buttocks and thighs. These cysts were filled with a glistening white paste, closely resembling certain shaving or face creams. This paste had a peculiar odour which was pronounced as "camphoraceous" by several observers independently. (No injections of camphor had been given). Microscopically masses of anisotropic acicular crystals and oily globules only were seen.

\section{DESCRIPTION OF PLATES.}

Figure $I$.

Photograph of Case III. showing the cystic swelling over the deltoid muscle.

Fisure 2.

Frozen section of the subcutaneous tissue in Case I. Stained with Hæmalum and Sudan III. High power view showing the crystals.

Figure 3 .

Microphotograph of a paraftin section of the skin and subcutaneous tissue in Case III. Low power view.

Figure 4 .

High power view of the same section, showing the giant cells and the clefts from which the crystals have been dissolved out in the paraffin process. 
Figure 5.

Case III. Paraffin section. High power view of an arteriole showing endarteritis. Figure 6.

Case III. Frozen section examined under the low power with Nicol's prisms incompletely crossed. Shows a cyst and the anisotropic crystal masses.

Figure 7 .

Case IV. Frozen section of subcutaneous fat under the low power with crossed Nicol's. Stained with Sudan III. Shows the anisotropic crystals lying free and in the fat globules.

Figure 8.

Frozen section of subcutaneous fat of a non-sclerematous (normal) infant. Low power. Crossed Nicol's. Sudan III. Shows the anisotropic crystals in the fat.

Figure 9.

Frozen sections, unstained. Polarising microscope: high power. Shows anisotropic crystals in sclerema and in a non-sclerematous infart's subcutaneous fat respectively.

Figure 10.

Anisotropic crystals in ether extracts of sclerema fat and normal fat respectively. Polarising microscope : $1 / 12$ objective.

Figure I1.

X-ray photograph of upper limbs in Case III. Shows opaque deposits in subcutaneous tissues, and outline of a cyst.

Figure 12. tissues.

X-ray photograph of lower limbs in Case V. Shows similar deposits in subcutaneous

(Part II. will appear in next Issue.) 